Our Nature
Journal homepage: http://nepjol.info/index.php/ON

\title{
Fish community structure along altitudinal gradients with relation to environmental variables in Ratuwa River of Eastern, Nepal
}

\author{
Dipak Rajbanshi ${ }^{1}$, Jash Hang Limbu ${ }^{2,3}$, Niraj Khadka ${ }^{4}$, Prakash Kumar ${ }^{1}$, Jeevan Kumar \\ Gurung $^{5}$ and Dil Kumar Limbu ${ }^{* 3}$ \\ ${ }^{1}$ Post Graduate Campus, Department of Zoology, Tribhuvan University, Biratnagar, Nepal \\ ${ }^{2}$ Nature Conservation and Health Care Council (NCHCC), Biratnagar, Nepal \\ ${ }^{3}$ Central Campus of Technology, Department of Biology, Tribhuvan University, Hattisar, Dharan, Nepal \\ ${ }^{4}$ Central Department of Zoology, Tribhuvan University, Kirtipur, Kathmandu, Nepal \\ ${ }^{5}$ Damak Multiple Campus, Department of Zoology Tribhuvan University, Damak, Jhapa, Nepal \\ *E-mail: dilklimbu@gmail.com
}

\begin{abstract}
Studies on fish community structure along altitudinal gradients of rivers are lacking in Nepal. This study was carried out to gauge the fish diversity and composition along elevational gradient in Ratuwa River. The altitudinal gradient varies between $70 \mathrm{~m}$ to $1300 \mathrm{~m}$. Fish samples were collected based on habitat representativeness from April (spring) 10-18, July (summer) 10-18, October (autumn) 10-18, 2020 and January (winter) 10-18, 2021. A total of 3447 specimens representing 4 orders, 14 families and 36 species were identified. Both fish diversity and abundance of studied ichthyofauna vary with altitudinal gradient. The present study affirmed that fish species of Opsarius bendelisis, Schistura multifasciatus, Garra annandalei, Brachydanio rerio, Aspidoparia morar, and Schistura scaturigina are the major contributory species (>1\%) for both space and time spectrums. Fish community structure testing for both to space and time showed significant difference in spatial spectrum $(R=0.72, P<0.01)$ but no significant difference in temporal variation $(R=-0.034, P>0.05)$. The present results hinted that fish assemblage structure varied significantly from low to high elevations, altitude, water temperature, water velocity, dissolved oxygen and $\mathrm{pH}$ was found as major influential factors $(P<0.05)$ for species distribution.
\end{abstract}

Key words: Altitude, freshwater, fish diversity, stream

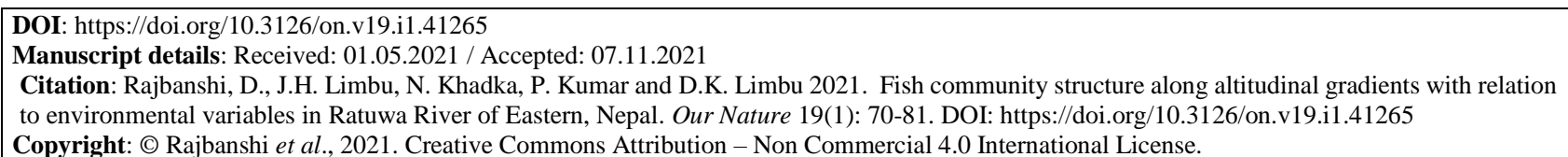

\section{Introduction}

Studies on fish community structure of freshwater fishes along the elevation gradient of rivers and streams are scanty in Nepal (Limbu and Prasad, 2020; Limbu et al., 2020; Prasad et al., 2020) and also studies on fish diversity in relation with environmental parameters and habitat, spatially and temporally aspects are very less (Limbu et al., 2021). Countless studies have been conveyed out on altitudinal models of species richness in mammals, birds and plants; but hardly any studies have been done in fish (Bhatt et al., 2012; Carvajal-Quintero et al., 2015). The falling off in species richness and extension in taxonomic 


\section{Rajbanshi, Limbu, Khadka, Kumar, Gurung and Limbu / Our Nature | December 2021 | 19 (1): 70-81}

distinctiveness with increasing elevation is a wellarchived circumstance in the flora and fauna (Rahbek, 1995; Lomolino, 2001). Broad land surface area is anticipated to assist more species and individuals under similar climatic conditions (Rahbek, 1995; Sanders and Rahbek, 2011). Biological interactions such as competition, predation, and productivity can control the occurrence of species and, to a greater extent, species richness (Whittaker, 2010; Stein et al., 2014). Broadly, the noticed model is blemished by lessen in species diversity and the substitution of species as elevation increases; however, the processes that determine those patterns to be left poorly observed (Lomolino, 2001).

Physical and chemical characteristics factors are imperative determinants of the condition of the fish species richness, abundance and distribution. For instance, habitat variables, such as substrate structure (Edds, 1986; Merz and Ochikubo Chan, 2005), flow rate and water velocity (Edds, 1986; Yu and Lee, 2002; Nelson and Lieberman, 2002), temperature (Vought et al., 1998; Kadye et al., 2008), stream size and altitude (Magalhaes et al., 2002; Gerhard et al., 2004) have been widely proved to influence fish

\section{Materials and Methods}

\section{Study Area}

The present study was conducted in the Ratuwa River and is situated in the part at Mangsebung Rural Municipality in Ilam district (Figure 1). The river originates from the Chure range at latitude $\left(26.656^{\circ}\right)$ and longitude $\left(87.705^{\circ}\right)$ and altitude $(1853 \mathrm{~m})$. River gradient decreases as the river surge into the relatively flat region in the lower Terai reaches $(1853 \mathrm{~m}-70 \mathrm{~m})$. The river substrata originate mostly erosion and weathering of sandstones in rainy season and can be characterized as fine to coarse sand, gravel, cobbles, pebbles and boulders. Alnus nepalensis is major community structure. Numerous studies (Edds, 1986; Mishra and Baniya, 2016; Pokharel et al., 2018; Limbu et al., 2019a, 2019b, 2020) have demonstrated the retaliation of different taxa along environmental variables in rivers. But, the review of literature shows that the study of fish diversity with relation to elevation, environmental variables and fish habitat aspects at different space and time scales are yet to be done.

There have been few studies that have described the patterns of ichthyofauna diversity along altitudinal gradients. It is critical to gain a better understanding of the diversity patterns of freshwater fish fauna across altitudinal gradients in order to determine how anthropogenic activities affect these patterns (e.g. hydroelectric dams, the introduction of exotic species, agriculture, deforestation and pollution). This data is necessary for developing successful conservation measures and mitigating the effects of human activity. Therefore, the aims of the study were to determine whether stream fish diversity varies with altitude and to evaluate which azoic element govern species richness and configuration.

natural vegetation for gradient $(600 \mathrm{~m}-1853 \mathrm{~m})$ and river bed is characterized as mostly big boulders, cobbles, pebbles and little sand. In contrary, Shorea robusta, Schima wallichii and the bushes are major natural vegetation for gradient $(600 \mathrm{~m}-70 \mathrm{~m})$ and river bed mostly consists of sand, cobbles, pebbles and gravels. From origin point to the few kilometers, river seems to be just like a canal and harbors no fish. It surges about $45 \mathrm{~km}$ towards the south and shows linkage with many canals and tributaries and finally discharges into Bay of Bengal, India. The river is blessed with both tropical and temperate climate which enable to advocate a wide biological diversity. 


\section{Rajbanshi, Limbu, Khadka, Kumar, Gurung and Limbu / Our Nature | December 2021 | 19 (1): 70-81}

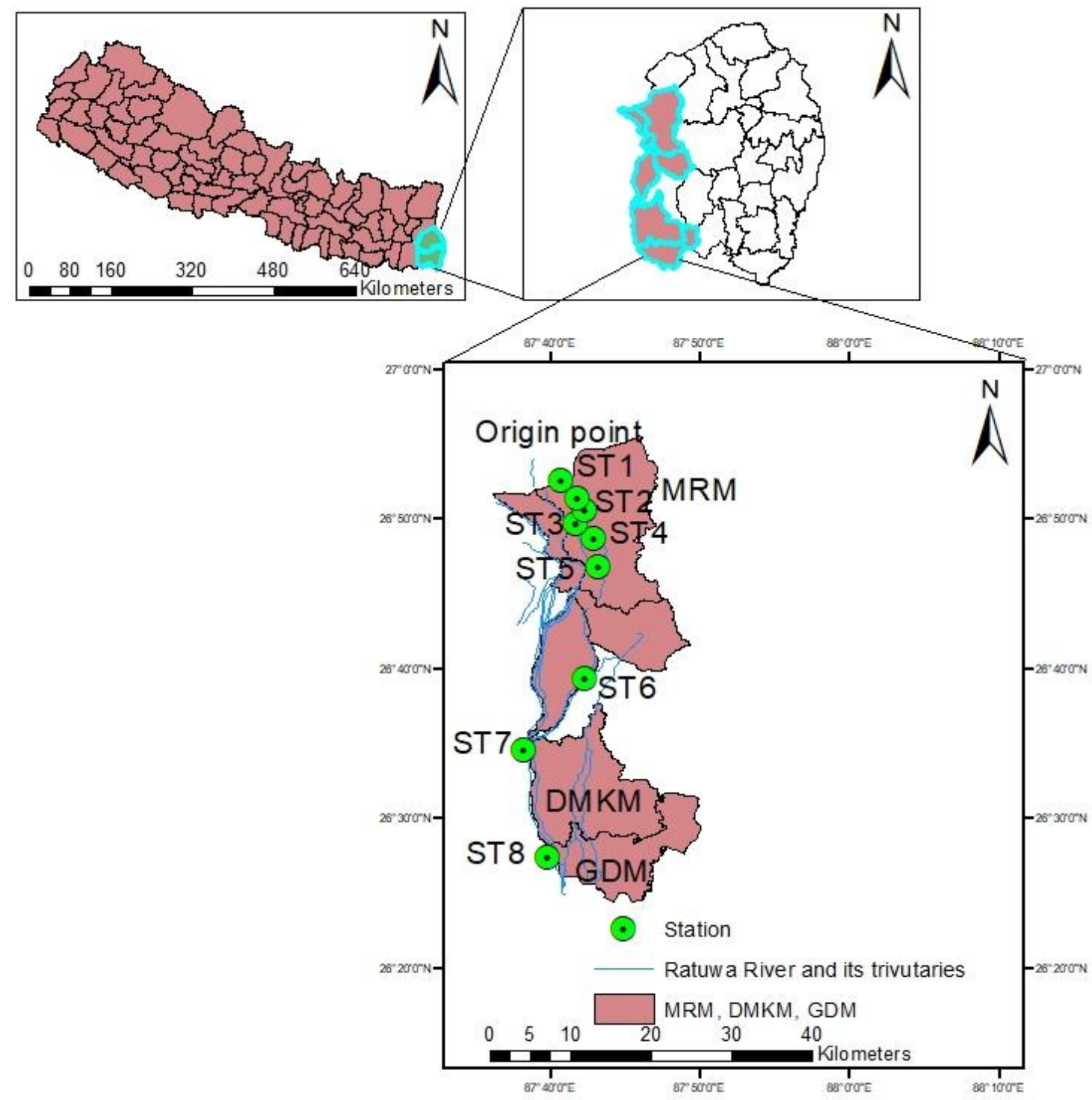

Figure 1. Map of study area indicating different stations ( $\mathrm{ST}=$ station) $(\mathrm{MRM}=$ Mangsebung Rural Municipality; DMKM = Damak Municipality; GDM = Gauradaha Municipality)

\section{Data Collection}

In this work, the altitudinal gradient of the studied sites varies between $70 \mathrm{~m}-1300 \mathrm{~m}$. We allocated altitudes into two altitudinal zones; STA: $70 \mathrm{~m}-600 \mathrm{~m}$ and STB; $600 \mathrm{~m}-1300 \mathrm{~m}$ (ST5, ST6, ST7 and ST8) for hydrological parameters and fish collection. Furthermore, fish samples were collected based on habitat representativeness from April (spring) 10-18, July (summer) 10-18, October (autumn) 10-18, 2020 and January (winter) 10-18, 2021. Based on the characteristics of the flow pattern, slope, average velocity and substrata components in the study area (Han, 2010; Huang et al., 2019; Limbu et al., 2021), the habitat types were categorized into three groups: lentic habitat (pool and steep pool), slow flow pattern (glide and run) and fast flow (riffle and cascade). Each sampling site was $200-250 \mathrm{~m}$ long with different habitat types (for instance, pool, steep pool, glide, run, riffle and cascade). For the fish sampling, two cast nets of different sizes were used, one having small mesh size of $0.5 \mathrm{~cm}, 3 \mathrm{~m}$ diameter and $2 \mathrm{~kg}$ weight and 


\section{Rajbanshi, Limbu, Khadka, Kumar, Gurung and Limbu / Our Nature | December 2021 | 19 (1): 70-81}

another having large mesh size of $2 \mathrm{~cm}, 6 \mathrm{~m}$ diameter and $6 \mathrm{~kg}$ weight, with the help of local fisher man. For the laboratory examination, about $10 \%$ collected fish were preserved in $10 \%$ formaldehyde solution in plastic jar by making their head upside for the protection of their caudal fin and after the photography, remaining samples were returned to their own natural habitat from where they were captured. The identification was done with the help of standard taxonomic references (Talwar and Jhingran, 1991; Jayaram, 2010; Shrestha, 2019; Fricke et al., 2021).

\section{Data Analysis}

To highlight the differences in environmental parameters (i.e, $\mathrm{pH}$, water temperature, dissolved oxygen and water velocity) and fish community attributes (i.e, Shannon index, Evenness index and Dominance index) between the different months, sites and altitude we executed analysis of variance (ANOVA) using the function aov in $\mathrm{R}$ software ( $\mathrm{R}$ core Team, Vienna, Austria). In the event of significance, a post hoc Tukey HSD test was used to determine which means were significantly different at a 0.05 level of probability (Spjotvoll and Sttoline, 1973). One-way analysis of similarities (ANOSIM) (Clarke, 1993) was used to test the significant difference among the spatial and temporal scales. To visualize the major contributing species both to space

\section{Results}

A total of 3447 specimens representing 4 orders, 14 families and 36 species were collected (Table 1). The ichthyofauna comprised mainly of Cypriniiformes (22 species) followed by Siluriformes (7 species), Synbranchiformes (3 species) and Anabantiformes (4 species). Total number of fish at each site varied from 1 to 594 individuals. Results from the similarity percentage analysis (SIMPER) showed that 24 species contributed more than $1 \%$. Of these, Barilius bendelisis, Schistura multifasciatus, Garra
Water temperature $\left({ }^{\circ} \mathrm{C}\right)$, dissolved oxygen (DO) $(\mathrm{mg} / \mathrm{l})$, water $\mathrm{pH}$, and water velocity were measured in-situ by a standard method (APHA, 2012), using a digital thermometer by placing it in the water at a depth of 1 feet for two to three minutes, DO meter (Model: DO5509, Lutron), pH meter (HI 98107, HANNA Instruments), whereas water velocity was measured by the float method with the help of a stop watch, plastic ball and measuring tape.

and time, similarity percentage (SIMPER) (Clarke, 1993) analysis was performed. Of 36 fish species, 6 species occurred in $<5 \%$ of the samples and removed from the analysis followed by Gauch (1982), who pointed out most of the multivariate analysis are influenced by rare species and are also outliers, thus obscuring the analysis of the data set as a whole. To verify the relationship between a spatial or temporal ordination of fish species and water parameters, the abundance matrix was pulled to Detrented Correspondence Analysis (DCA) and the gradient length was estimated. As the gradient length obtained from DCA was long 5.67 indicating Canonical Correspondence Analysis (CCA) was more applicable to verify the existence of fish species and azoic factors.

annandalei, Brachydanio rerio, Aspidoparia morar, and Schistura scaturigina were the abundant species both to spatial and temporal spectrums. One-way analysis of similarity (ANOSIM) testing for both spatial and temporal variations in fish community suggested that there was a significant difference in spatial spectrum $(R=0.72, P<0.01)$ but no significant difference in temporal variation $(R=-0.034, P>0.05)$. Species richness sequentially increased from station (ST1-ST3) but decreased in station (ST4).

Table 1. Fish species collected from Ratuwa River.

\begin{tabular}{|c|c|c|c|}
\hline Order & Family & Code & Species \\
\hline \multirow[t]{5}{*}{ Cypriniformes } & Cyprinidae & Sp1 & Labeo bata Day, 1877 \\
\hline & Cyprinidae & $\mathrm{Sp} 2$ & Garra annandalei Hora, 1921 \\
\hline & Cyprinidae & Sp3 & Puntius terio Hamilton-Buchanan, 1822 \\
\hline & Cyprinidae & Sp4 & $\begin{array}{l}\text { Puntius sophore Hamilton-Buchanan, } \\
1822\end{array}$ \\
\hline & Cyprinidae & Sp5 & $\begin{array}{l}\text { Puntius conchonius Hamilton-Buchanan, } \\
1822\end{array}$ \\
\hline
\end{tabular}


Rajbanshi, Limbu, Khadka, Kumar, Gurung and Limbu / Our Nature | December 2021 | 19 (1): 70-81

\begin{tabular}{|c|c|c|c|}
\hline & Cyprinidae & Sp6 & Schizothorax plagoistomus Day, 1877 \\
\hline & Danionidae & Sp7 & Barilius barila Hamilton, 1822 \\
\hline & Danionidae & Sp8 & Opsarius bendelisis Hamilton, 1822 \\
\hline & Danionidae & Sp9 & Opsarius vagra Hamilton, 1822 \\
\hline & Danionidae & Sp10 & Aspidoparia morar Day, 1878 \\
\hline & Danionidae & Sp11 & Raiamas guttatus Day, 1869 \\
\hline & Danionidae & Sp12 & $\begin{array}{l}\text { Brachydanio rerio Hamilton-Buchanan, } \\
1822\end{array}$ \\
\hline & Danionidae & Sp13 & Danio devario Day, 1878 \\
\hline & Danionidae & Sp14 & Esomus danricus Hamilton, 1822 \\
\hline & Psilorhynchidae & Sp15 & Psylorhynchus balitora Day, 1877 \\
\hline & Cobitidae & Sp16 & $\begin{array}{l}\text { Acanthocobotis } \quad \text { botia } \quad \text { Hamilton- } \\
\text { Buchanan, } 1822\end{array}$ \\
\hline & Nemacheilidae & Sp17 & Schistura multifaciatus Menon, 1987 \\
\hline & Nemacheilidae & Sp18 & Schistura scaturigina Menon, 1987 \\
\hline & Nemacheilidae & Sp19 & $\begin{array}{l}\text { Schistura sovana Hamilton-Buchanan, } \\
1822\end{array}$ \\
\hline & Nemacheilidae & Sp20 & Schistura horai Menon, 1951 \\
\hline & Nemacheilidae & Sp21 & Schistura rupecula McClelland, 1838 \\
\hline & Cobitidae & Sp22 & $\begin{array}{l}\text { Lepidocephalus guntae } \quad \text { Hamilton- } \\
\text { Buchanan, } 1822\end{array}$ \\
\hline Siluriformes & Bagridae & $\mathrm{Sp} 23$ & Mystus cavasius Jayaram, 1977 \\
\hline & Bagridae & Sp24 & Mystus vittatus Bloch, 1797 \\
\hline & Bagridae & Sp25 & Mystus tengara Misra, 1976 \\
\hline & Sisoridae & Sp26 & $\begin{array}{l}\text { Gogangra viridescens Hamilton- } \\
\text { Buchanan, } 1822\end{array}$ \\
\hline & Sisoridae & Sp27 & $\begin{array}{l}\text { Pseudolaguvia kapuri Tilak and Husian, } \\
1974\end{array}$ \\
\hline & Claridae & Sp28 & Clarius batrachus Linnaeus, 1758 \\
\hline & Heteropneustidae & Sp29 & Heteropneustes fossilis Bloch, 1794 \\
\hline Synbranchiformes & Synbranchidae & Sp30 & $\begin{array}{l}\text { Monopterus cuchia Hamilton-Buchanan, } \\
1822\end{array}$ \\
\hline & Mastacembelidae & Sp31 & $\begin{array}{l}\text { Macrognathhus pancalus Hamilton- } \\
\text { Buchanan, } 1822\end{array}$ \\
\hline & Mastacembelidae & $\mathrm{Sp} 32$ & Mastacembalus armatus Lacepede, 1800 \\
\hline Anabantiformes & Anabantidae & Sp33 & Anabas testudineus Bloch, 1795 \\
\hline & Osphronemidae & Sp34 & $\begin{array}{l}\text { Colisa fasciatus Bloch and Schneider, } \\
1801\end{array}$ \\
\hline & Channidae & Sp35 & Channa punctatus Bloch, 1793 \\
\hline & Channidae & Sp36 & Channa stewarti Playfair, 1867 \\
\hline
\end{tabular}

Altitude had a significant effect on the fish community parameters. Species richness was negatively related to elevation $(r=-0.67)$ and species richness per site ranged from 5 to 22 species (Table 2), whereas there was a positive correlation between Shannon-Weiner diversity index and dominance index $(r=0.88)$. In contrary, both Shannon-Weiner diversity index and Dominance index were negatively related to elevation ( $r=-0.56$ and $r=-0.33$ ). Highest number of individuals was found at elevation between 71 $\mathrm{m}$ to $200 \mathrm{~m}$ with decrease at higher elevations (Fig. 2).

Table 2. Showing spatial abundance and richness of fish species in different stations and different altitude.

\begin{tabular}{cccc}
\hline Station & Altitude & Abundance & $\begin{array}{c}\text { Species } \\
\text { richness }\end{array}$ \\
\hline A & 1300 & 163 & 5
\end{tabular}


Rajbanshi, Limbu, Khadka, Kumar, Gurung and Limbu / Our Nature | December 2021 | 19 (1): 70-81

\begin{tabular}{cccc} 
B & 1000 & 85 & 6 \\
C & 700 & 119 & 8 \\
D & 300 & 60 & 9 \\
E & 189 & 75 & 9 \\
F & 125 & 168 & 15 \\
G & 98 & 201 & 21 \\
H & 71 & 215 & 18 \\
A & 1300 & 65 & 5 \\
B & 1000 & 52 & 6 \\
C & 700 & 71 & 8 \\
D & 300 & 49 & 4 \\
H & 189 & 75 & 10 \\
F & 125 & 172 & 16 \\
G & 98 & 141 & 21 \\
H & 71 & 43 & 16 \\
A & 1300 & 20 & 5 \\
B & 1000 & 22 & 6 \\
C & 700 & 13 & 7 \\
D & 300 & 35 & 5 \\
E & 189 & 68 & 7 \\
F & 125 & 99 & 12 \\
G & 98 & 75 & 16 \\
H & 71 & 99 & 12 \\
A & 1300 & 91 & 5 \\
B & 1000 & 123 & 9 \\
C & 700 & 82 & 5 \\
D & 300 & 59 & 6 \\
E & 189 & 158 & 14 \\
F & 125 & 300 & 22 \\
G & 98 & 216 & 20 \\
H & 71 & & \\
& & 916 & 5 \\
\hline
\end{tabular}

(a)

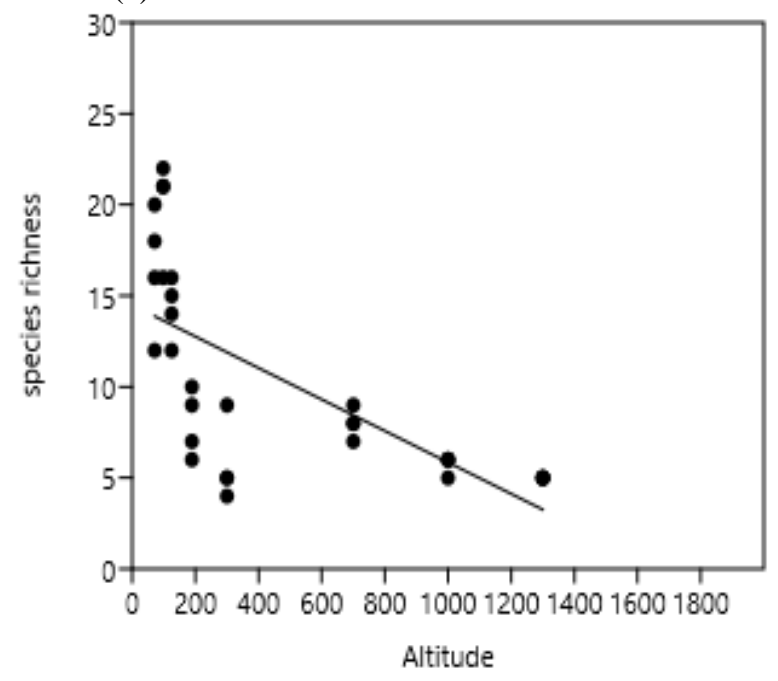

(b)

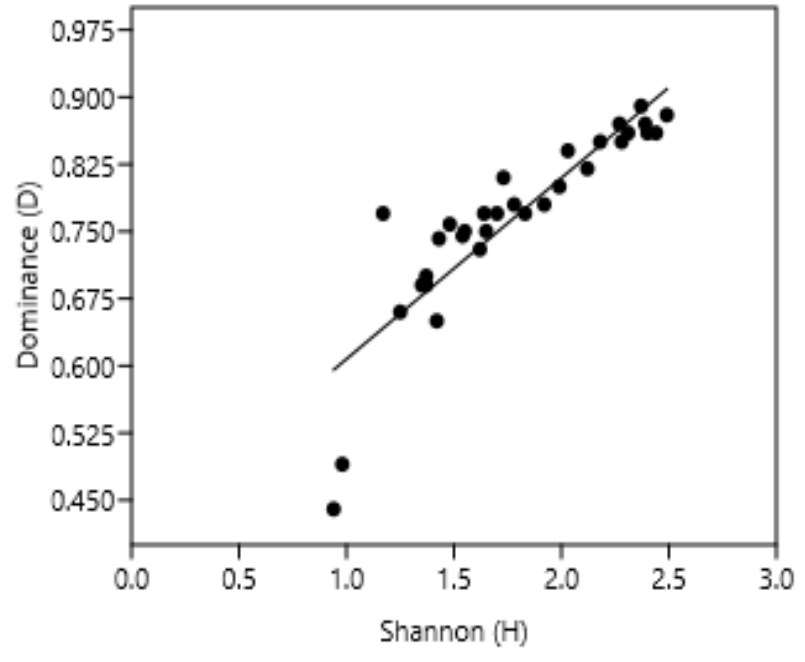


(c)

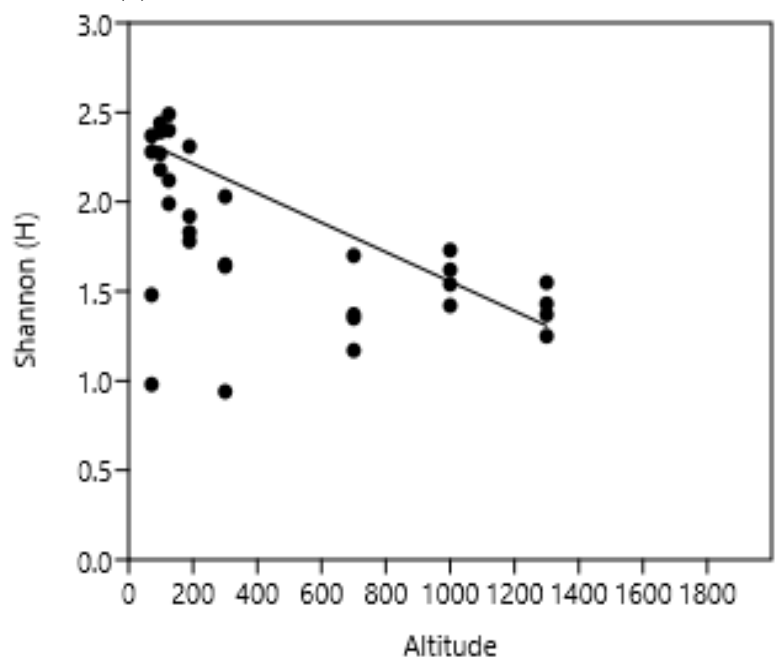

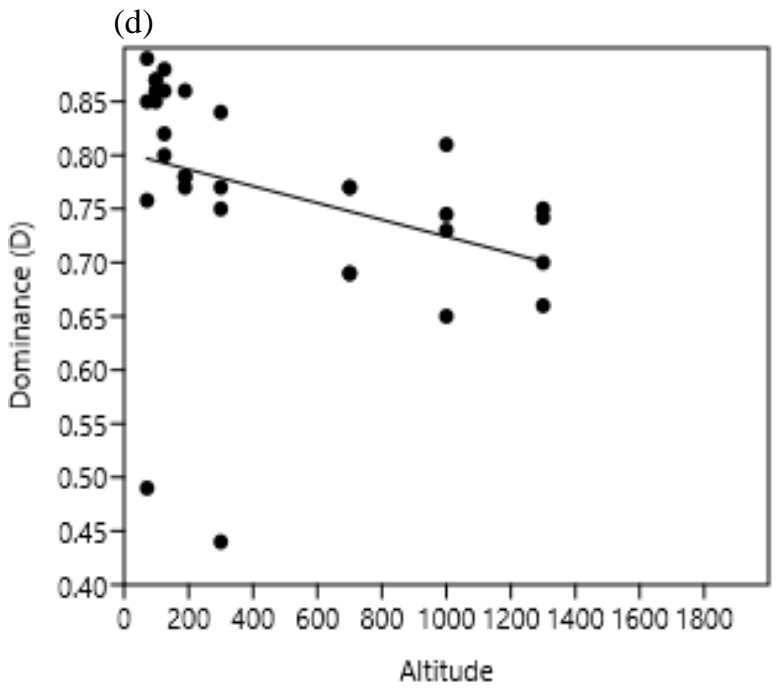

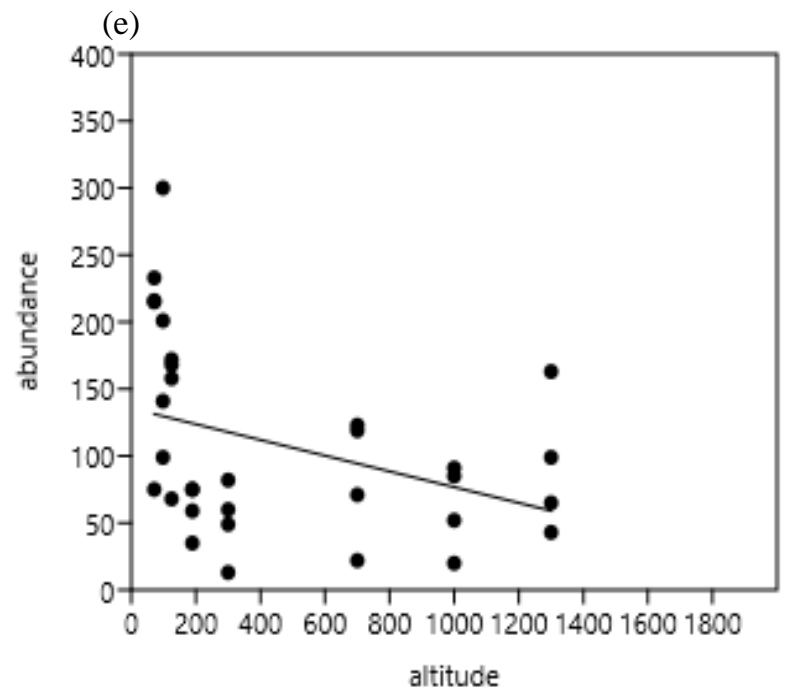

Figure 2. Regression models between species richness (a), Shannon-Weiner_H vs dominance index_D; (b), Shannon_H vs Dominance_D; (c) Altitude vs Shannon_H; (d), Altitude vs Dominance_D; (e), Altitude vs Abundance, abundance and the elevation gradient in the Ratuwa River.

The first and second axis of canonical correspondence analysis (CCA) explained 53\% of the total variance $(37 \%$ on the first axis and $16 \%$ on the second axis). The CCA biplot indicated the relationship between fish species and environmental variables (Figure 3 ). The first axis obtained from CCA explained a gradient associated with water velocity, $\mathrm{pH}$ and water temperature. The fish species associated with these environmental factors (water velocity and $\mathrm{pH})$ were $\mathrm{sp} 1, \mathrm{sp} 5, \mathrm{sp} 8, \mathrm{sp} 10, \mathrm{sp} 29, \mathrm{sp} 30$ and sp31. On the contrary, fish species, sp4, sp7, sp9, sp11, sp13, sp14, sp21, sp22, sp23, sp24, sp25, and sp28 were highly associated with water temperature. While the second axis explained the variables of dissolved oxygen (DO) and altitude. Fish species, sp2, sp12, sp15, sp16, sp18 and sp21 were highly associated altitude. On the other hand, species of sp6, sp17, sp19 and sp20 were linked with dissolved oxygen. Analysis of CCA indicated that all the selected environmental 


\section{Rajbanshi, Limbu, Khadka, Kumar, Gurung and Limbu / Our Nature | December 2021 | 19 (1): 70-81}

factors greatly influence $(F=5.41, P<0.05)$ the

fish community structure in Ratuwa River.

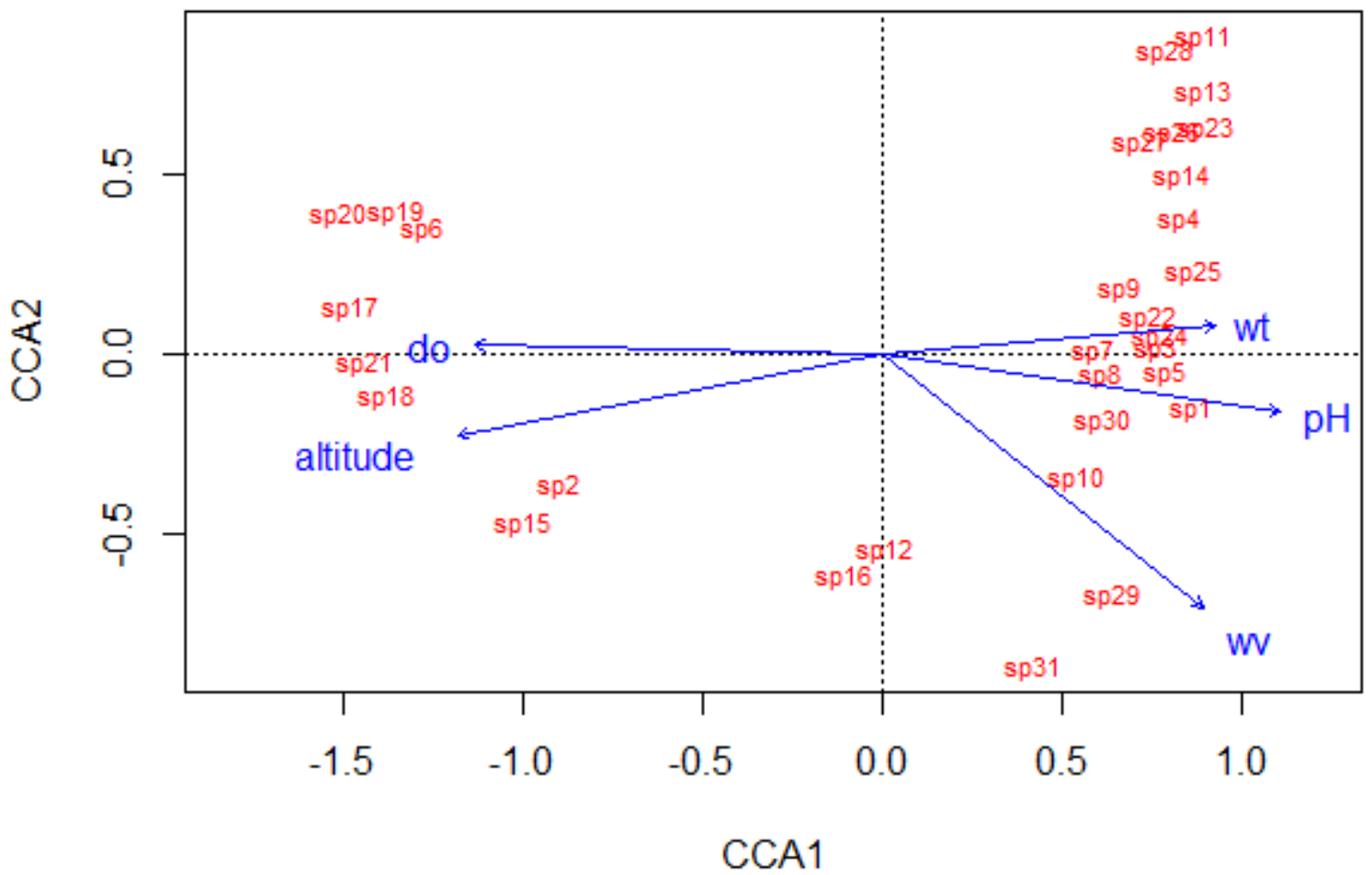

Figure 3. Biplots from canonical correspondence analysis (CCA) for the fish community structure in Ratuwa River $(\mathrm{do}=$ dissolved oxygen, $\mathrm{wt}=$ water temperature, $\mathrm{wv}=$ water velocity; for species code please see Table 1$)$

\section{Discussion}

The present study examined ichthyo-fauna community structure along elevation gradients in Ratuwa River of eastern Nepal. Our results hinted that fish assemblage structure varied significantly from low to high elevations. This is due to unalike fish species distribution and composition, which can be affected by environmental variables such as elevation, area of elevation band (Cruz-Elizalde et al., 2016), and productivity (Wright et al., 2003). Our study is also in agreement with studies of fish species in the eastern Europe (Askeyev et al., 2017), stream of Northen east Algeri (Benzina et al., 2019), Yangtze River basin (Fu et al., 2004), in the southern Appalachians (Robinson and Rand, 2005), in eastern Nepal Himalaya (Khatiwada et al., 2019), in Himalaya (Bhatt et al., 2012), and in the central Andes (Jaramillo-Villa et al., 2010), which have described that the diversity of aquatic fauna decreased gradually with altitude. The species richness or diversity in the uplands lessened significantly along the altitudinal gradient, which hints that the environmental factors of the high land or altitude might serve as a barrier to scatter and the colonization of adjacent drainage basins by lowland fishes (Pouilly et al., 2006; Jaramillo-Villa et al., 2010).

Our multivariate analysis indicated that altitude, dissolved oxygen, water velocity, water temperature and $\mathrm{pH}$ were significant $(F=5.41, P<0.05)$ contributors in shaping the species distribution. Water temperature (Kadye et al., 2008; Limbu et al., 2021) and dissolved oxygen (Pouilly et al., 2010; Limbu et al., 2019) have already been shown to affect the fish community. Besides, current velocity ( $\mathrm{Yu}$ and Lee, 2002; Li et al., 2012), depth (Vlach et al., 2005; Kadye et al., 2008), width (Gerhard et al., 2004), substrate (Vlach et al., 2005; Limbu et al., 2020), altitude (Magalhaes et al., 2002; Bhatta et al., 2012), conductivity (Yu and Lee, 2002) and climate (Magalhaes et al., 2002) have all been shown to influence fish species distribution. Fish species, Schistura multifasciata, S. sovana, S. horai, $S$. scaturigina, S. rupecula and Schozothrax plagiostomus showed positive response to elevation. Only those 


\section{Rajbanshi, Limbu, Khadka, Kumar, Gurung and Limbu / Our Nature | December 2021 | 19 (1): 70-81}

species which has been well adapted to highland, rapid flowing habitats and exhibit number of morphological modifications in their lips, body shape and size and also other associated structures and color patterns (Wang et al., 2006). This study demonstrated that the acknowledgement of the distinctive upstream ichthyofauna to altitudinal gradient range diverse from that of species populating downstream rivers.

Our present results suggested that the Shannon index decreased with elevation. The fish diversity of common of typical species in the community decreased on an elevational gradient (Askeyev et al., 2017). Similarly, Simpson's index also did the same as Shannon but did not support the previous studies (Jaramillo et al., 2010; Askeyev et al., 2017). Only Schistura spp were dominated above $700 \mathrm{~m}$. This can be explained of the fish abundances to the existing available natural resources (Matthews, 1998; Askeyev et al., 2017). Fish diversity and total abundance showed unimodal response to elevation (Askeyev et $a l ., 2017)$. The highest fish numbers were recorded at elevation between 71 and $200 \mathrm{~m}$. Our study suggested that the species richness and abundance increased with decreased elevation. A similar pattern has been

\section{Acknowledgements}

We would like to thank Mr. Manish Rai for the help of fish sampling and transportation. We are highly indebted to Dr. Bharat Raj Subba for fish identification. Our special thanks go to Damak

\section{References}

Adhikari, A, J.H. Limbu and P. Somika. 2021. Fish Diversity and Water Quality Parameters of Mechi River, Jhapa, Province No. 1, Nepal. Borneo Journal of Resources Science and Technology 10(2): 24-34. https://doi.org/10.33736/bjrst.2954.2021

American Public Health Association (APHA). 2005. Standard Methods for the Examination of Water and Wastewater, 21st ed., Washington, DC: American Public Health Association.

Askeyev, A, S. Monakhov, I. Askeyev and O. Askeyev. 2017. Rare and endangered fish species distribution in relation to environmental gradients, Tatartstan Republic, Russia. Proceedings of Scientific Works of Institute of Problems Ecology and Mineral Wealth, Kazan, pp 3-15. reported elsewhere water bodies (Rahbek, 1995; Lomolino, 2001; Bhatta et al., 2012; Askeyev et al., 2017). According to those studies, species richness in the upstream dampened significantly, with a reduction of $3.3-17.0 \%$ of the total number of species present along the altitudinal gradient. The higher species richness and abundance of fish increased could be influenced by many factors such as sufficient amount of food availability, water velocity, volume, width, depth, vegetation and topography.

Our analysis of similarity (ANOSIM) testing for both spatio-temporal variations in fish community suggested that there was a significant difference in spatial spectrum $(R=0.72, P<0.01)$ but no significant difference in temporal variation $(R=-0.034, P>0.05)$. This type of spatio-temporal spectrum of variation in ichthyo-faunal diversity observed in our study is also found in other river systems (Yan et al., 2010; Li et al., 2012; Limbu et al., 2020; Shrestha et al., 2020; Adhikari et al., 2021; Limbu et al., 2021). In addition, the extremely low $R$ value suggested that seasons are not major factors to influence the species variation but the spatial spectrum significantly changed the species variation.

Multiple Campus, Tribhuvan University, Department of Environment Science, Damak, Jhapa for providing us different water sampling kits.

Benzina, I, S.B. Abdelkrim, G. Cherif, S. Frederic and C. Régis. 2019. How altitudinal gradient affects the diversity and composition of benthic insects in arid areas streams of northern East Algeria. Biologia, 75: 567-577.

Bhatt, J.P, K. Manish and M.K. Pandit. 2012. Elevational gradients in fish diversity in the Himalaya: water discharge is the key driver of distribution patterns. PLoS One, 7(9):e46237

Carvajal, Q.J.D, F. Escobar, F. Alvarado, F.A. VillaNavarro, U. Jaramillo-Villa and J.A. Maldonado-Ocampo. 2015. Variation in freshwater fish assemblages along a regional elevation gradient in the northern Andes, Colombia. Ecology and Evolution, 5(13): 2608-2620. doi: 10.1002/ece3.1539

Clarke, K.R. 1993. Non-parametric multivariate analyses of changes in community structure. 


\section{Rajbanshi, Limbu, Khadka, Kumar, Gurung and Limbu / Our Nature | December 2021 | 19 (1): $70-81$}

Australian Journal of Ecology, 18: 117-143. https://doi.org/10.1111/j.1442-

9993.1993.tb00438.x

Cruz-Elizalde, R, A. Ramírez-Bautista, X. Hernández-Ibarra, and L.D. Wilson. 2016. Species diversity of amphibians from arid and semiarid environments of the Real de Guadalcázar State Reserve, San Luis Potosí, Mexico. Natural Areas Journal, 36: 302-309. https://doi.org/10.3375/043.036.0310

Edds, D.R. 1986. Fishes of Klai Gnagaki/Narayani Rivers, Nepal. Journal of Natural History Museum, 10(14): 14-22.

Fu, C, J. Wu, X. Wang, G. Lei and J. Chen. 2004. Patterns of diversity, altitudinal range and body size among freshwater fishes in the Yangtze River basin, China. Global Ecology and Biogeography, 13: 543-52.

Fricke, R, W.N. Eschmeyer and R. van der Laan (eds). 2021. Eschmeyer's Catalog of Fishes: Genera, Species, References (http://researcharchive.calacademy.org/researc h/ichthyology/catalog/fishcatmain.asp).

Electronic version accessed dd mmm 2021.

Gauch, H.G.J. 1982. Multivariate analysis in community ecology. Cambridge: Cambridge University Press.

Gerhard, P, R. Maraes and S. Molander. 2004. Stream fish communities and their associations to habitat variables in a rain forest reserve in southeastern Brazil. Environmental Biology of Fishes, 71: 321-340. https://doi.org/10.1007/s10641-004-1260-y

Han, Y.Q. 2010. Studies on fish species diversity and evolution trend in Lijiang River. Journal of Hydroecology, 3: 132-135.

Huang, L.L, W. Zhiqiang, M. Yuanmin, Z. Naicheng, W. Qi, and C. Zhongbing. 2019. Correlation of fish assemblages with habitat and environmental variables in a Headwater Stream Section of Lijiang River, China. Sustainability: 1-14. https://doi.org/10.3390/su11041135

Huh, S.H and C.L. Kitting. 1985. Trophic relationships among concentrated populations of small fishes in seagrass meadows. Journal of Experimental Marine Biology and Ecology, 92: 29-43. https://doi.org/10.1016/00220981(85)90020-6

Jaramillo-Villa, U, J.A. Maldonado-Ocampo and F. Escobar. 2010. Altitudinal variation in fish assemblage diversity in streams of the Central
Andes of Colombia. Journal of Fish Biology, 76: 2401-2417. https://doi.org/10.1111/j.10958649.2010.02629.x

Jayaram, K.C. 2010. The freshwater fishes of Indian region. Narendra Publishing House, Delhi, India, 614.

Kadye, W.T, C.H.D Magadza, N.A.G. Moyo. And S. Kativu. 2008. Stream fish assemblages in relation to environmental factors on a montane plateau. Environmental Biology of Fishes, 83: 417-428. https://doi.org/10.1007/s10641-0089364-4

Keskin, C and N. Unsal. 1998. The Fish Fauna of Gokceada Island, NE Aegean Sea. Turkey. Italian Journal of Zoology, 65: 299-302. https://doi.org/10.1080/11250009809386836

Khatiwada, J.R, T. Zhao, Y. Chen, W. Wang, D.C. Cannatella and J. Jiang. 2019. Amphibian community structure along elevation gradients in eastern Nepal Himalaya. BMC Ecology, 19: 1-11. https://doi.org/10.1186/s12898-0190234-z

Li, J. H, L.L. Huang, L. M. Zou, Y. Kano, T. Sato and T. Yahara. 2012. Spatial and temporal variation of fish assemblages and their associations to habitat variables in a mountain stream of north Tiaoxi River, China. Environmental Biology of Fishes, 93: 403-417. https://doi.org/10.1007/s10641-011-9928-6

Limbu, J.H and S. Gupta. 2019. Fish diversity of Damak and lower Terai region of Ratuwa River of Jhapa district, Nepal. International Journal of Fauna and Biological studies, 6(01-04)

Limbu, J.H, G.S. Acharya and O.M. Shrestha. 2018. A brief report on ichthyofaunal diversity of Dewmai Khola of Ilam district, Nepal. Journal of Natural History Museum, 30: 312-317. https://doi.org/10.3126/jnhm.v30i0.27607

Limbu, J.H, J.K. Gurung, S. Subba, N. Khadka, A. Adhikari and C.B. Baniya. 2021b. An Impact Assessment of Betani Irrigation Dam on Fish Diversity of Damak Municipality, Jhapa, Nepal. Egyptian Journal of Aquatic Biology and Fisheries 25(2): 163-175. https://dx.doi.org/10.21608/ejabf.2021.161363

Limbu, J.H, S. Subba, J.K. Gurung, J. Tumbahangfe and B.R. Subba. 2021a. Correlation of fish assemblages with habitat and environmental variables in the Phewa Khola Stream of Mangsebung Rural Municipality, Ilam, Nepal. 


\section{Rajbanshi, Limbu, Khadka, Kumar, Gurung and Limbu / Our Nature | December 2021 | 19 (1): $70-81$}

Journal of Animal Diversity, 3(1): 27-36. http://dx.doi.org/10.52547/JAD.2021.3.1.5

Limbu, J.H and A. Prasad. 2020. Environmental variables and fisheries diversity of the Nuwa River, Panchthar, Nepal. Scientific World, 3: 69-74. https://doi.org/10.3126/sw.v13i13.30542

Limbu, J.H, C.B. Baniya and A. Prasad. 2019a. Spatio-Temporal Variation of Fish Assemblages in Ratuwa River, Ilam, Nepal. Journal of Ecology \& Natural Resources, 3(3): 000168.

Limbu, J.H, B. Bhurtel, A. Adhikari, G.C. Punam, M. Maharjan and S. Sunuwar. 2020. Fish community structure and environmental correlates in Nepal's Andhi Khola. Borneo Journal of Resources Science and Technology, 10(2): 85-92. https://doi.org/10.33736/bjrst.2510.2020

Limbu, J.H, N. Chapagain, S. Gupta and S. Sunuwar. 2019b. Review on fish diversity of eastern Nepal. International Journal of Fisheries and Aquatic Studies, 7(3): 177-181.

Limbu, J.H, J.K. Gurung, S. Subba, N. Khadka, A. Adhikari and C.B. Baniya. 2021. An Impact Assessment of Betani Irrigation Dam on Fish Diversity of Damak Municipality, Jhapa, Nepal. Egyptian Journal of Aquatic Biology and Fisheries, 25(2): 163-175. DOI: 10.21608/EJABF.2021.161363

Limbu, J.H, A. Prasad and O.M. Shrestha. 2018. Ichthyofaunal diversity of Bakraha River of Morang district, Nepal. International Journal of Fisheries and Aquatic Studies, 6(5): 267271.

Lomolino, M.V. 2001. Elevation gradients of speciesdensity: historical and prospective views. Global Ecology and Biogeography, 10: 3-13. https://doi.org/10.1046/j.1466822x.2001.00229.x

Magalhaes, M.F, D.C. Batalha and M.J. CollaresPereora. 2002. Gradients in stream fish assemblages across a Mediterranean landscape: contributions of environmental factors and spatial structure. Freshwater Biology, 47: 1015-1031. https://doi.org/10.1046/j.13652427.2002.00830.x

Magurran, A.E. 1988. Ecological Diversity and its Measurement. Princeton University Press, Princeton.
March, J.G, J.P. Benstead, C.M. Pringle and F.N. Scatena. 2003. Damming tropical island streams: Problems, solutions, and alternatives. Bioscience, 53: 1069-1078. https://doi.org/10.1641/00063568(2003)053[1069:DTISPS]2.0.CO;2

Merz, J. R. and Ochikubo, C. L. K. 2005. Effects of gravel augmentation on macroinvertebrate assemblages in a regulated California river. River Research and Applications, 21: 61-74. https://doi.org/10.1002/rra.819

Mishra, A.R and C.B. Baniya. 2016. Ichthyofaunal Diversity and Physico-chemical Factors of Melamchi River, Sindhupalchok, Nepal. Journal of institute of science and technology, 21(1), 10-18. https://doi.org/10.3126/jist.v21i1.16031

Nelson, J. 2007. Fishes of the World. Fourth Edition. Hoboken, New Jersey, John Wiley and Sons.

Nelson, S.M and D.M. Lieberman. 2002. The influence of flow and other environmental factors on benthic invertebrates in the Sacramento River, USA. Hydrobiologia. 489: 117-129. https://doi.org/10.1023/A:1023268417851

Oksanen, J, F.G. Blanchet, R. Kindt, P. Legendre, P.R. Minchin, R.B. Ohara, G.L. Simpson, P. Solymos, M. Henry, H. Stevens et al. 2015. Vegan: Community ecology package. R package version 2.3-1. Available from: http://CRAN.R-project. org/package=vegan

Pokharel, K.K, B.B. Khadga, C.M. Trilok and B.B. Chitra. 2018. Correlations between fish assemblage structure and environmental variables of the Seti Gandaki River Basin, Nepal. Journal of Freshwater Ecology, 33(1): 31-43. https://doi.org/10.1080/02705060.2017.13991 70

Pouilly, M, S. Barrera and C. Rosales. 2006. Changes of taxonomic and trophic structure of fish assemblages along an environmental gradient in the Upper Beni watershed (Bolivia). Journal of Fish Biology, 68: 137-156. doi:10.1111/j.1095-8649.2005.00883.x

Prasad, A, A. Shrestha, J.H. Limbu and D. Swar. 2020. Spatial and temporal variation of fish assemblage structure in Seti Gandaki River, Tanahu, Nepal. Borneo Journal of Resources Science and Technology, 10(2): 93-104. https://doi.org/10.33736/bjrst.2048.2020 


\section{Rajbanshi, Limbu, Khadka, Kumar, Gurung and Limbu / Our Nature | December 2021 | 19 (1): $70-81$}

Rahbek, C. 1995. The elevational gradient of species richness: a uniform pattern? Ecography, 18: 200-205. https://doi.org/10.1111/j.16000587.1995.tb00341.x

Robinson, J.L and P.S. Rand. 2005. Discontinuity in fish assemblages across an elevation gradient in a southern Appalachian watershed, USA. Ecology of Freshwater Fish, 14: 14-23. https://doi.org/10.1111/j.1600-0633.2005.00063.x

Ryer, C.H and R.J. Orth. 1987. Feeding ecology of the Northern pipefish, Syngnathus fuscus, in a Seagrass community of the lower Chesapeake Bay. Estuaries, 10 (4): 330-336. https://doi.org/10.2307/1351891

Sanders, N.J and C. Rahbek. 2011. The patterns and causes of elevational diversity gradients. Ecography, 35: 1-3. doi: 10.1111/j.16000587.2011.07338.x

Shannon, C.E and W. Wiener. 1949. The mathematical theory of communication. Urbana, Uiversity of Illinois Press, pp: 177.

Shrestha, J. 2001. Taxonomic revision of fishes of Nepal. In: Biodiversity, agriculture and pollution in South Asia. (Eds. P.K. Jha et.al.). ECOS, Kathmandu. pp. 171-180.

Shrestha, J.N. 2016. Fish diversity of Triyuga River, Udayapur District. Our Nature, 14(1): 124-134. https://doi.org/10.3126/on.v14i1.16452

Shrestha, J. Singh, D. M. and Saund, T. B. 2010. Fish diversity of Tamor River and its major tributaries of eastern Himalayan region of Nepal. Nepal Journal of Science and Technology: 219-223. https://doi.org/10.3126/njst.v10i0.2964

Shrestha, T. K. 2019. Ichthyology of Nepal, A study of fishes of the Himalayan waters. Himalayan Ecosphere, Kathmandu, Nepal.

Simonov, E.A, O.I. Nikitina and E.G. Egidarev. 2015. River flood adaptation in the Amur Basin and nature conservation. Use and Protection of Natural Resources of Russia Bulletin, 3: 15-24.

Spjotvoll, E and M.R. Stoline. 1973. An extension of the T-method of multiple comparisons to include the cases with unequal sample sizes. Journal of the American Statistical Association, $\quad$ 68: $\quad 975-978$. https://doi.org/10.1080/01621459.1973.10481 458
Talwar, P.K and A.G. Jhingram. 1991. Inland Fisheries of India and Adjacent Countries. Volume I and II. Oxford and IBH Publishing Co. India, 1158.

Stern, A, K. Gerstner and H. Kreft. 2014. Environmental heterogeneity as a universal driver of species richness across taxa, biomes and spatial scales. Ecology Letters, 17: 866-80. DOI: 10.1111/ele.12277 TerBraak, C.J.F. 1986. Canonical correspondence analysis-a new eigenvector technique for multivariate direct gradient analysis. Ecology, 67(5): 11671179. https://doi.org/10.2307/1938672

Vlach, P, J. Dusek, M. Svatora and P. Moravec. 2005. Fish assemblage structure, habitat and microhabitat preference of five species in a small stream. Folia Zoologica, 54: 421-431.

Vought, L.B.M, A. Kullberg and R.C. Petersen. 1998. Effect of riparian structure, temperature and channel morphometry on detritus processing in channelized and natural woodland streams in southern Sweden. Aquatic Conservation Marine and Freshwater Ecosystem, 8: 273-285.

Wang, Q, X.Z. Yuan, H. Liu and Y.W. Jang. 2011. Rapid assessment model for mountain stream habitat and its application. Journal of Hydraulic Engineering, 42: 928-933.

Whittaker, R.J. 2010. Meta-analyses and megamistakes: calling time on meta-analysis of the species richness-productivity relationship. Ecology, 91: 2522-33. DOI: 10.1890/080968.1

Wright, S, R.D. Gray and R.C. Gardner. 2003. Energy and the rate of evolution: inferences from plant rDNA substitution rates in the western Pacific. Evolution, $\quad 57$ : 2893-2898. https://doi.org/10.1554/03-044

Yan, Y, H.E. Shan, C.H.U. Ling, X. Xiuying, J.I.A. Yanju, T.A.O. Juan, and C. Yifeng. 2010. Spatial and temporal variation of fish assemblages in a subtropical small stream of the Huangshan Mountain. Current Zoology, 56(6): 670-677. https://doi.org/10.1093/czoolo/56.6.670

Yu, S.L and T.W. Lee. 2002. Habitat preference of the stream fish, Sinogastromyzon puliensis. Zoological studies, 41: 183-187. 